\title{
A multi-case study of instructional decision-making processes of teachers in kindergarten classrooms within the Cape Coast Metropolis, Ghana
}

\section{Mumuni Thompson}

Department of Basic Education. College of Education Studies. Faculty of Educational Foundations. University of Cape Coast. Ghana. E-mail: tmumuni@ucc.edu.gh.

\begin{abstract}
The study contributes to the ongoing debate with respect to the significance of early childhood teachers' instructional decision-making that take in consideration their theoretical knowledge (explicit theories) and practical experiences (implicit theories) and how they impact their instructional decision-making processes in diverse socio-cultural contexts of children. To address this gap in the literature, a qualitative multi-case study into the perceptions and classroom practices of four kindergarten teachers in two Ghanaian schools, Tata and Kariba, was carried out from May to November 2015. One research questions guided the study, namely: What factors and beliefs influence teachers' instructional decision-making in a kindergarten classroom? Data sources used were semi-structured individual interviews and pair-based interviews and field notes of classroom observations. Both within and across case interpretative analysis was used. The study's findings revealed that these teachers' explicit theories and implicit theories of teaching influenced their instructional decision-making processes in kindergarten classrooms. It was recommended that future researchers should explore early childhood teachers' explicit and implicit theories of teaching. It was also recommended kindergarten teachers to appreciate their roles as effective instructional decisions makers towards quality teaching and learning.
\end{abstract}

Keywords: Preschool; Elementary school; Primary school; Kindergarten classroom; Childhood development.

Resumo: Estudo de caso múltiplo de tomada de decisão de processos instrucionais de professores de jardim de infância em Cape Coast, Gana. 0 estudo contribui para o debate em curso a respeito da importância da tomada de decisão instrucional de professores da primeira infância que leva em consideração seus conhecimentos teóricos (teorias explícitas) e experiências práticas (teorias implícitas) e como eles impactam seus processos decisórios instrucionais, em diversos contextos socioculturais das crianças. Para resolver esta lacuna na literatura, um estudo qualitativo de caso múltiplo sobre as percepções e práticas de
Received:

Apr. 16, 2018

Accepted:

Apr. 27, 2018

Released:

Apr. 30, 2018

Open access

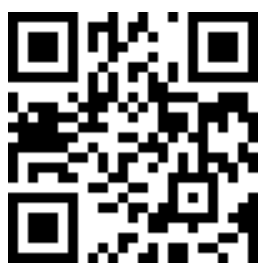

ORCID

(ㄱ) 0000-0001-7480-6849

Mumuni Thompson 
sala de aula de quatro professores de jardim de infância em duas escolas de Gana, Tata e Kariba, foi realizado entre maio e novembro de 2015. Uma pergunta da pesquisa que questionou o estudo foi: quais fatores e crenças influenciam a tomada de decisão instrucional dos professores em uma sala de aula? As fontes de dados utilizadas foram entrevistas individuais semiestruturadas e entrevistas baseadas em pares, bem como notas de campo de observações em sala de aula. Análises interpretativas dentro e entre os casos foram usadas. As descobertas do estudo revelaram que as teorias explícitas desses professores e as teorias implícitas de ensino influenciaram seus processos de decisão instrucional nas salas de aula do jardim de infância. Foi recomendado que futuros pesquisadores explorassem as teorias explícitas e implícitas dos professores da primeira infância sobre o ensino. Também foi recomendado que os professores de jardim de infância apreciassem seus papéis como responsáveis pelas decisões instrucionais eficazes em relação ao ensino e ao aprendizado de qualidade.

Palavras-chave: Pré-escolar; Escola elementar; Escola Primária; Jardim de infância; Desenvolvimento infantil.

\section{Introduction}

Research into teachers' thinking on how to make informed instructional decisions, has been an area of research interests to researchers in early childhood education over a decade. Several studies (Berliner, 1994; Yasmin and Andre, 2012) regarding teachers' reflective practices which mostly focus on comparative analysis of preservice teachers' instructional decision-making processes have provided valuable insights with respect the cognitive processes involved in teachers' instructional decision-making processes. The study's finding revealed deficiencies that are closely-linked to instructional decision-making processes of preservice teachers and further recommended the need to empower the teachers to develop theoretical and practical insights regarding instructional decision-making in diverse kindergarten settings. However, these insights reflected the views of preservice early childhood teachers, accordingly, there is the need to explore how kindergarten teachers make their instructional decisions.
Though, extensive academic research has explored early childhood teachers' instructional practices (Hyson et al., 1990; Maxwell et al., 2001; Horn and Ramey, 2004; Hedge and Cassidy, 2009), but much less research has investigated teacher' instructional decision-making processes in early childhood settings (Bernstein, 1975; Spodek, 1988a; Mitchell, 1994). As teachers continue to make instructional decisions, this conveys the need for research that extends beyond the daily encounters of teachers with children in kindergarten classroom context. This need is illustrated in many ways: For example, children come to every learning contexts with certain uniqueness in terms of interest, learning needs and potentials. Nevertheless, It takes early childhood educators who have theoretical and practical insights into instructional decision-making to make decisions which would inturn, impact individual children's development in diverse ways.

It is increasingly evident that effective instructional decision-making would continue to be a critical 
component of effective teaching and learning in early childhood settings. The processes leading to an informed instructional decision-making forms a critical component of effective teaching because it give teachers insights into learning materials, learning activities and instructional strategies that are likely to work during teaching. Instructional decisions prior to the commencement of a lesson provide teachers opportunities to anticipate factors that are likely to enhance their effectiveness thereby not subjecting successful instructional delivery to chance. Although, some academic researchers have acknowledged a need for a greater understanding in this area (Bredekamp, 2014), little is known about how kindergarten teachers within the Cape Coast Metropolis make their instructional decisions. To further early childhood educators understanding, the instructional decision-making process of kindergarten teachers within the Cape Coast Metropolis was explored.

The main thrust of this study is to determine how teachers put their theoretical knowledge about instructional decisions into practice. Precisely, we sought to understand whether teachers' theoretical knowledge about instructional decision making is closely linked to the quality of instructional decision they make before, during and after every teaching and learning episode.

Having insights into the connection between teachers' theoretical knowledge about instructional decisional decision-making processes in early childhood settings, would further broaden our understanding regarding how the needs, interests and individuality that children bring to every learning context is factored into their decision-making.

In this article our focus is to establish whether increased theoretical knowledge and practical experiences improve teachers' ability in making informed instructional decisions which would in turn, impacts children's development in diverse ways.

Many educators believe that the most informed teachers are, the greater the likelihood that the teachers' practices in classrooms can impact positively on children's development. Moreover, teachers' deeper insights into their practices would enable them to make informed instructional decisions regarding pre-lesson preparation, during and after the end of every instructional segment. By implication, teachers' instructional decision-making in early childhood settings appears to be influenced by explicit theories of teaching and implicit theories of teaching. However, Spodek (1988b) maintains that teachers' explicit theories of teaching evolve because teachers tend to process information as they interact with children in class. Through this mechanism, they come to understand certain concepts and values that they have gathered over the years of their practice as teachers. Hence, teachers' actions and instructional decisions are usually influenced by their perceptions and beliefs. These factors tend to influence their views about their practices as teachers. These impressions held by teachers stem from their beliefs, ideas or theories they hold implicitly. As Spodek (1988b) suggests, these interpretations eventually become the foundation for teachers' practices in early childhood classrooms. Spodek (1988b) further argues that for a better understanding of the role of teachers, there is the need to understand the implicit theories that constitute their guiding principles while taking instructional decisions. Spodek (1988b), therefore, asserts that implicit theory refers to instructional ideas that teachers develop from personal experience based on practical experiences over a period. Spodek (1988b) further maintains that for a long time, most early childhood educators conceived of teaching in early 
childhood settings as a practical application of the scientific field of how young children develop.

Meanwhile, some studies were conducted in the past to explore teachers' implicit theories in classroom settings. For example, Bernstein (1975) explored ideologies influencing early childhood programmes in England concluding that there is a hidden pedagogy or implicit theories of teaching that influence teacher practices in infant schools that serve children from age five to seven. Mitchell (1994) in a study which investigated teachers' implicit theories concerning how teachers ask questions in class during teaching concluded that most teachers believe that to ensure an effective setting for questioning, students should be comfortable with both the teacher and their peers. The implication is that effective questioning tends to be influenced by the learning environment that teachers create in classrooms. However, Spodek (1988b) in a study which explored the implicit theories of early childhood teachers revealed that there is more to teaching than just having firm grasps of the principles of teaching. In other words, there is more to teaching than just what is visible about the activities of teachers in their classrooms. The study's findings further revealed that in moments of solitude teachers might be still functioning as a teacher because they might be contemplating on an earlier topic taught in class or a topic they are planning to teach in class. Teachers while teaching function in a consistent manner and this makes it possible for them to predict what is likely to take place before, during and after every teaching process. Thus, there is the need for more research into how explicit and implicit theories of teaching impact teachers' instructional decision-making in kindergarten classrooms.

The research question driving the study was what factors and beliefs influence teachers' instructional decision-making processes in a kindergarten classroom?

\section{Method}

This article is a sequel to Annobil and Mumuni (2018).

\section{Participants}

The study consisted of four participants. The pseudonyms of the participants and their respective schools were Kate and Sophia from Tata School, and Ramatu and Akotia from Kariba School, purposively sampled from two kindergarten classrooms sited in different socio-economic contexts within the Cape Coast Metropolis, Ghana.

Kate, has taught for 25 years while Sophia has taught for 19 years. Ramatu has taught for, 9 years, Akotia on the other hand has taught for 7 years. While both Kate and Sophia have bachelors' degrees in early childhood education, Ramatu and Akotia on the other hand, have diploma in early childhood education. A multi-case qualitative study approach was used in this study because I want to establish the differences regarding teachers' practices in Tata School and Kariba School sited in different socio-economic settings.

\section{Instruments}

Two main instruments were used for this study. These included semistructured interviews and observations. The interviews made it possible for the researcher to gain insights into participants' perspectives about their practices in kindergarten classrooms. The participants were interviewed in pairs once and individually twice. Interviewing teachers in pairs provided a platform for them to share their rich experiences each other and the researcher as well. Other reasons for interviewing the researcher several times included the following; first, it enabled me to establish the consistencies of the responses of the participants across the interview sessions. It allowed 
for the interviewees to talk at length and elaborate because they were given the opportunity to react to questions multiple times. It allowed the interviewees to talk at length and elaborate because they were given the opportunity to react to questions multiple times. The interviews were conducted at a time when children were on break. In all, each of the visits to the classrooms lasted one hour. In the second phase, observation took place in all the two kindergarten classrooms. The observations provided an opportunity for me to determine how teachers level of knowledge about their practices unfolded in real-life classroom context. During my observations, on occasion, and in an unobtrusive manner as possible, I conversed with the kindergarten teachers while the children were engaged in certain small group activities or individual activities to seek clarifications from them reasons for engaging children in various kinds of activities. After, the end of every lesson, I engage them in a discussion for about ten minutes to seek further clarifications on certain issues. This process of interacting with the teachers provided each one of them an opportunity to clarify an issue that was perplexing to me arising while observing the teachers' instructional practices in the classrooms. That is during these sort of activities, each of the teachers were seen moving from one group to another giving guidance to the children on how to accomplish a task whenever any of them encountered a challenge. This method provided an opportunity for me to observe and interact with the teachers two or three times during the study. Because my focus in this study is to explore teachers' perspectives about their practices in the classrooms. Field notes rather than recording, reduced such intrusions. Such observations allowed me to enactment of issues beyond self-reporting because how teachers describe their actions and how their actions unfold in real-life teaching and learning context differ. The observations of the teachers were done after each of the teachers have been interviewed. Apart from been a technique of for generating primary data, observations serve as a check on the other data collection method. This method was used to check individual biases that likely to be exhibited in the in-depth interviews. Also, the gathering of data using two research instruments allow for triangulation of data.

\section{Procedure}

The instruments were administered to the participants in the two case schools from May to November 2015. The data analyses were on case by case basis to identify key themes within each of the cases to answer the research questions. The teachers' thoughts were audio recorded and transcribed verbatim. The teachers' thoughts were further organised into categories. The themes that emerged from the analyses were further validated by the observational data. In short, the themes were determined through open and axial coding (Boeijie, 2010). From the analyses above, it can be concluded that a theme is a pattern across data sets that is important to the description of a phenomenon which is linked to a research question.

\section{Results}

In particular, the study's results are reported as follows: the case of two teachers at the southern school, Tata; the case of two teachers at the Northern school, Kariba; and finally, a cross-case analysis.

\section{Case study analyses of the teachers at the Southern school (Tata) processes Instructional decision-making}

The results of the study revealed that, the two teachers made instructional decisions before, during and after every lesson. In addition, the teachers' instructional decision-making processes 
appeared to have been influenced by professional factors (instructional strategies suggested in the curriculum, their professional education), the teachers' experiences, the teachers' reflection in action, and the teachers' reflection on action (Pedretti, 1996).

\section{Professional factors}

While both Kate and Sophia valued instructional strategies suggested in the kindergarten curriculum and used them to inform their instructional decision-making process, both teachers further perceived their professional education as a basis for their instructional decision-making processes. The reader is reminded that Kate and Sophia completed a 4-year degree (B. ED) in early childhood education. Nonetheless, the two teachers saw the impact of professional factors on their decision-making in similar ways.

Kate: My professional training has broadened my knowledge about how [children learn] because it has helped me to know the various stages of children's development and how to handle them and at every stage. It has also helped me to know the behaviour pattern of children and what to do.

Sophia: My professional training helps me to take the age and the needs of the individual children into consideration when selecting learning materials because early childhood education has made me understand how children learn.

While both teachers felt that their professional education helped them understand how children learn, Kate appreciated how her knowledge about children's stages of development helped her know how to respond to children's behaviour in class whereas Sophia felt such knowledge permitted her to attend to learning needs of her children. Thus, the teachers' professional education backgrounds gave them different insights into how to make well-informed instructional decisions.

Moreover, Kate and Sophia further provided other reasons for how their professional education impacted their instructional decision-making.

Kate: This knowledge that I have about children helps me to select instructional strategies which are suitable for young children. Also, it has helped me to understand that children learn through hands-on experiences, so when I am teaching, I provide the needed learning materials for the children to interact with.

Sophia: Knowing the developmental stages of children help me to select topics and teaching strategies that are useful to the children.

For Kate, her knowledge about how children learn helped her make effective instructional decisions by selecting appropriate learning materials and instructional strategies for her lessons. Sophia, on the other hand, perceived that her knowledge about children's level of development helped her select topics and methods that were appropriate for children in her class.

\section{Teaching experiences}

Both Kate and Sophia saw their instructional decision-making processes in a kindergarten classroom as a function of their previous teaching experiences (Kate: 25 years teaching K; Sophia: 19 years teaching $\mathrm{K}$ ). However, there were similarities and differences regarding how both teachers perceived its impact.

Kate: My teaching experiences help me revisit my teaching. It helps me re-adjust my teaching by repeating some of the activities and methods to develop children's fine motor skills before I move further to the next topic.

Sophia: My experiences in early childhood classrooms always guided 
me to select learning activities and methods of teaching which are useful for the development of young children.

Thus, for Kate, her experiences (both with these children and other previous years) gave her clues as to whether the teaching methods and activities she was using was effective or not. However, she modifies them whenever there was the need to do so, while for Sophia, her experiences served as a clue for selecting effective activities and instructional strategies during prelesson preparation.

\section{Teachers' reflection in action}

Both Kate and Sophia also valued reflection in action (a means of making instructional decisions in during teaching) as a means of instructional decision-making in their kindergarten classroom. However, they spoke of it somewhat differently.

Kate: If I am using a method which is making it difficult for the children to understand what I am teaching, I do change the method in the process of teaching."

Sophia: If the strategy I am using is effective, you will see the children contributing to the discussion. But if it is not their attention would be diverted from what we are doing in class.

Kate was of the view that she used children's lack of understanding of concepts during teaching as a cue for modifying her instructional strategies. Sophia, however, was of the view that the inattentiveness of children in the class was a signal that the instructional strategy she was using is not effective.

\section{Teachers' reflection on action}

Both Kate and Sophia valued reflection on action (a means of making instructional decisions after teaching) as an effective means of instructional decision making in kindergarten settings. However, the teachers described different feedback, written or oral, as cues for their reflections.

Kate: After I have taught a lesson I sit down to think about what I did in class. For example, we have some workbooks so after the activities when I mark their work, and they did not do well I reflect to see whether it was because of the method that they did not get the information right or not. So, when I come to class next time I revisit the topic.

Sophia: After a lesson, I reflect on whatever I taught in class. It helps me to know whether what I did was right or wrong If I found out that they did not understand the lesson because they [could not answer the questions] that I asked them, I will ask myself whether I should teach the lesson again or part of it.

Both Kate and Sophia perceived that they assessed the effectiveness of a lesson that they had delivered in a class by reflecting on it. While Kate told us that the low scores of children in a class exercise suggested that the instructional strategy used during the lesson might not have been effective, Sophia, nonetheless, used the inability of children to respond to questions in class as a signal that the lesson was not well delivered.

In sum, evidence from the data appears to suggest that the instructional decision-making processes of these teachers in this study were directly and indirectly informed by their pedagogical training, experiences and reflective practices. Nonetheless, there were similarities and differences regarding how these factors impacted their instructional decision-making processes.

\section{Case study analyses of teachers at Northern school (Kariba)}

The second case study was conducted at Kariba School, which was 
sited in a rural setting. As in the previous case, the analyses of both teachers, Ramatu and Akotia, interview responses produced several themes which address each of the four research questions.

\section{Instructional decision-making processes}

As regards the fourth research question, the analyses of the teachers' interviews transcripts indicated that these two teachers made instructional decisions before, during and after every lesson. Indeed, professional factors (instructional strategies suggested in the curriculum, teachers' professional education), the teachers' experiences, the teachers' reflection in action, and the teachers' reflection on action appeared to have informed the teachers' instructional decision-making processes.

\section{Professional factors}

Both Ramatu and Akotia valued instructional strategies suggested in the mandated curriculum and used it to inform their instructional decisionmaking process not only because doing so was useful in planning their curriculum, but also because they also felt comfortable using the strategies.

However, both teachers indicated that they modified the instructional strategies suggested in the kindergarten curriculum whenever there was the need to do so.

Ramatu: But the strategies are suggestions because when they were researching into them, they use a different environment. So, the strategy might not be useful in our situation. So, I use a different strategy if the one suggested in the syllabus is not working.

Akotia: Some of the teaching strategies outlined in the curriculum such as think-pair-share is good for language and literacy lessons in schools where children are allowed to express themselves freely. So, they are not timid. But the children in this school are coming from homes where parents take all decisions. So, when they come to school, and I [use] such a strategy, the children would not even contribute. So, as a class teacher, I know the children in my class better than any other person. So, I will not go in for such a strategy but will look for a strategy that will be effective in our case.

Both Ramatu and Akotia perceived that the socio-cultural contexts which informed the design and development of the instructional strategies might not align with the sociocultural contexts of the children they teach. So they modified the strategies to suit their contexts when they judged it necessary do so.

In a similar vein, both Ramatu and Akotia perceived that their professional education impacted (3-year diploma in ECE) their instructional decision-making process. Nonetheless, there were similarities and differences inherent in how they perceived it.

Ramatu: I did early childhood education, so it has helped me to understand how children learn and what I am expected to do in class to enhance their learning.

Akotia: I know how children learn so this knowledge that I have about children help me to select learning materials and methods of teaching that are suitable for young children.

For both Ramatu and Akotia, their insights about children, gained through their education programmes, enabled them to understand how children learn. Akotia further elaborated how she used her insights about children to promote their development. Nevertheless, Ramatu connects 'how children learn' to specifics like the selection of learning materials and teaching methods.

Indeed, Ramatu further explained how her insights into how children learn 
and how she was expected to relate to the children in class impacted her instructional decision-making in her kindergarten setting. She elaborated:

Ramatu: In this class, I engage the children in a lot of hands-on activities. But as a means of encouraging them to learn, I always make sure that they see me as one of them because when I come to their level, they will feel at home and this will enhance their learning. So, in class, I behave like them, sing like them and dances like them.

For Ramatu, teaching and learning in kindergarten classrooms was more effective if a kindergarten teacher created a learning environment which recognised children as partners in the teaching and learning process.

\section{Teaching experiences}

Both Ramatu and Akotia perceived that their teaching experiences impacted their instructional decisionmaking processes (i.e. Ramatu, 9 years teaching K; Akotia, 7 years teaching K). Both teachers had a similar perception of its impact.

Ramatu: The experiences that I have had in teaching young children help me to choose the right learning materials for the children. Children would only understand a concept if the learning materials I am using is familiar to them. So, as I interact with them, I get to know the materials to choose for them.

Akotia: [My experiences] help me select learning materials which are familiar to the kids because they can easily relate to those materials. If I am teaching about fruits and cite grapes as an example, the children will not understand because it is not familiar to them. But if I use mangoes as examples, the children will understand because they have eaten it before, so it is familiar to them.
For both Ramatu and Akotia, their previous teaching experiences (both with these children and others in previous years) informed them that learning materials which are familiar to children tended to be effective in class and this, in turn, influenced their selection of learning materials in subsequent lessons.

\section{Teachers' reflection in action}

Both Ramatu and Akotia pointed to reflection in action (a means of making instructional decisions during teaching) as a means of instructional decisionmaking in a kindergarten setting.

Ramatu: When I am teaching, I get feedback from the children. The feedback I get from the children will tell me whether the instructional strategy I am using is working or not. If it is not working, there is the need for me to use a different strategy. But as a teacher, I know that it is not helpful for me to rely on only one teaching strategy. So, during prelesson planning, I consider two or more other strategies so that if the one I am using is not working, I can go in for a different one.

Akotia: As I teach, I evaluate the lesson to see whether they are getting what I am teaching. For example, I might ask one or two questions as I am teaching to find out if they are getting what I am teaching. This process would help me determine whether the strategy I am using is helping them or not.

Thus, both Ramatu and Akotia used cues from the children to assess their level of understanding of the concepts taught in class. While Ramatu speaks of feedback from children, she did not explicitly reveal the nature of the feedback and whether or not it was related to children's understanding. However, Akotia specifies that she assessed the children's understanding (by asking questions) and implied that the lack of correct answers signalled that 
her instructional strategy was not working. These teachers, therefore, perceived that it was their actions and decisions, that impacted children's learning. As such, it would seem that Ramatu and Akotia did not subscribe to the deficit model of the child.

\section{Teachers' reflection on action}

Also, Ramatu and Akotia spoke of reflection on action (a means of making instructional decisions after teaching) as another means of instructional decisionmaking.

Ramatu: After I have taught a lesson, I reflect to see if I did the right thing. When I realised that the lesson was not well, taught I look for information from different text books to help me teach the lesson again. For example, if I did not say something I should have said, I make sure that I teach the lesson again".

Akotia: Anytime I finish teaching a lesson; I sit down to think about it to see if there was something I did not do right. If I realise that there was something I needed to do during the lesson, but I did not do, I prepare for the following week and teach the lesson again.

Both Ramatu and Akotia acknowledged that they always assessed the effectiveness of every lesson they deliver in a class by pondering over whether it was successful or not. Interestingly, both speak of right and wrong and seem to relate it to "missing information". Moreover, both teachers use a remedial lesson to rectify the situation. While Ramatu was explicit about how she prepared for the remedial lesson, Akotia was not.

Overall, then, evidence from the data appear to suggests that the instructional decision-making processes of the participants in this study were informed by their professional education backgrounds, their experiences and reflective practices. However, there were similarities and differences regarding how these factors impacted their decision-making.

\section{Across case analyses}

To further understand the ways in which kindergarten teachers make instructional decisions, across-case analyses (by school) is reported next. As might be expected, some of the themes reported within each case were unique to that case. With regard to kindergarten teachers' perceptions about their instructional decision-making processes, across-case analyses (by school) indicates that all the themes reported in each case were common to all four teachers across the cases, notwithstanding the school setting in which they taught.

Across the cases, the participant's valued professional factors (strategies suggested in the curriculum and professional education) in their instructional decision-making in kindergarten settings. Irrespective of context, all four teachers used the strategies suggested in the curriculum in their decision-making. Moreover, the role of socio-cultural contexts while apparent in both cases, Tata School and Kariba School, it was Kate and Sophia at Tata School and Akotia from Kariba School who linked it to the selection of teaching methods. Likewise, the participants in the cases believed their knowledge about how children learn in kindergarten settings impacted their practices. Regardless of context, all the four teachers used their insights about how children learn during their lesson preparation. While those teachers at Tata School reported that it served as the basis for selecting instructional strategies, the teachers at Kariba School, on the other hand, perceived its impact differently. While Ramatu linked it to the selection of learning materials, Akotia, however, saw it as means of creating learning environments that see the teacher and the children as partners in the teaching and learning process. 
Across cases, teachers believed their previous, and current teaching experiences impacted their instructional decision-making in their kindergarten classrooms. However, at Tata School in an urban setting, the teachers' spoke of its impact on the selection of teaching methods while Sophia further linked it to the selection of learning activities. In Kariba Schoool, such experiences informed the teachers' selection of learning materials. Thus, in both cases, the teachers perceived its impact on their decision-making differently.

Across cases, the participants valued reflection in action as one of the means of instructional decision-making in kindergarten classrooms. Regardless of context, the four teachers used it to assess the impact of their practices on children's learning. While Kate from Tata School and Ramatu from Kariba School, spoke of modifying their practice based on such reflection, this was not overly discussed by Sophia and Akotia from Kariba School.

Likewise, reflection on action as one of the effective means of instructional decision-making processes was apparent in kindergarten classrooms across cases. Irrespective, of the school setting, the teachers used such reflections. While all four teachers spoke of determining the effectiveness of their practice by such reflection, it was only Kate at Tata School who reported the low scores of children in class assignments as a determinant of an ineffective lesson.

In summary, then, comparisons of the emergent themes across the two cases, and thus across all four kindergarten teachers indicate only minor differences based on the rural and urban contexts in which these classrooms were located. Likewise, no distinct patterns could be seen with regard to years of experience or level of education. However, the findings do point to nuanced reasoning and beliefs about developmentally appropriate practices associated with individual teacher's perspectives. Thus, while many commonalities with each other, the mandated curriculum, and the interpretations of DAP in the broader ECE literature, existed, the ways in which each teacher illustrated and articulated her perceptions point to subtle discrepancies that are worthy of further investigation.

\section{Discussion}

As the findings of the current study revealed, these four kindergarten teachers believed that instructional decision-making was based on diverse factors including reflective practice, while there were differences and similarities regarding how these informed their practice, theories of teaching was a common thread. Interestingly, these teachers' comments pointed towards both explicit theories (professional factors; instructional strategies suggested in the curriculum, teacher education backgrounds) and implicit theories (teachers' experiences, reflection on action and reflection on action) of teaching, guiding their decisions, before and during lessons.

As elaborated by all participants, effective instructional decision-making before the commencement of a lesson in their kindergarten classrooms was linked closely to explicit theories of teaching. This suggested that teachers' ability to make a well-informed instructional decision before the start of a lesson is dependent to some extent on instructional strategies outlined in the kindergarten curriculum. This is not surprising because Ghana practices a centralised and controlled curriculum, whereby these teachers were expected to make their instructional decisions within the bounds of the frame of the curriculum. Teachers' professional backgrounds are implicated in instructional decision-making before the commencement of a lesson to the extent that it provided theoretical knowledge, understanding and insights into the usefulness of strategies they would find 
in the curriculum documents. For example, the kindergarten curriculum in Ghana outlines the content, learning activities, lesson objectives and assessment procedures that are significant for the evaluation of a lesson. In this vein, the professional background of the teacher to some extent plays a significant role in the interpretation of the curriculum for instructional decisionmaking. However, as these kindergarten teachers attest, teaching experience also contributes to their interpretation of the curriculum, especially, regarding the selection of instructional strategies which have proven effective and have aligned with their children's sociocultural contexts of children they have taught in previous years. Thus, while research informed the designing of the kindergarten curriculum, it is challenging for such a curriculum to take into consideration, the differences regarding children's specific social contexts. For instance, as revealed in the current, study, teachers' critical analyses of the prescribed curriculum when determining which instructional strategy to choose might reveal its ineffectiveness in a particular kindergarten setting thereby, resulting in the teachers' use of an alternative one. Thus, drawing on personal repertoires of knowledge and experiences, these kindergarten teachers tended to interpret curriculum materials to both inform and support effective teaching and learning in kindergarten classrooms. As such, these participants, even in a centralised education context (i.e. a top-down curriculum model), did not perceive the curriculum materials as cast in stone, but rather as something they can modify when there is the need to do so. In this vein, explicit theories, namely those that were explicated from outside sources such as their professional training, the mandated curriculum and their years of experience, guided them to contextualise such prescriptions in developmentally appropriate ways. What remains unknown is the weight individuals might afford one or another of these in circumstances where the theories were not aligned.

Also, these four participants indicated that implicit theories of teaching were instrumental to effective teaching and learning in these kindergarten classrooms. Accordingly, during and after instruction, these Kindergarten teachers used certain cues as a means of addressing some impediments that they believed were mitigating against effective delivery of their lessons. For example, cues such as children's lack of attentiveness in class and low scores in classroom assignments were indicators of the ineffectiveness of their lessons, even when they were peculiar to a few individual children and not the entire class. Thus, these teachers use such cues in reciprocal ways by assessing children's level of understanding and taken the needed remedial when necessary, which in turn, implicitly enhanced and promoted individual children's understanding of concepts taught in class. This points then to the significance of these teachers' reflective practices in making informed instructional decisions while teaching (and afterwards). It would appear then these Ghanaian teachers' practices align well with the premise that in early childhood settings individualised teaching should be emphasised because children's abilities differ (Copple and ', 2009; Bredekamp, 2014). Indeed, these teachers' descriptions of effective instructional decision-making during and after their lessons coincide with views that a kindergarten teacher is expected to function in multiple ways, by assessing grounds of failure and taking remedial measures to deal with the situation at hand and in subsequent lessons (Spodek, 1988b; Mathew, 2012). Indeed, the current study's emerging evidence of these teachers' reflection-on-action and in-action points to a role early childhood teachers' implicit theories of teaching (i.e. garnered through experience and 
reflection) play in their instructional decision-making processes.

\section{Conclusion}

It is also apparent from the study that two major factors appear to inform the instructional decision-making processes of the teachers, and these included teachers' explicit theories of teaching and their implicit theories of teaching. It is therefore, suggested that future research should explore early childhood teachers' implicit theories of teaching.

The study demonstrated the potentials that exist for the use of explicit and implicit theories of teaching in early childhood settings to inform teachers' reflective practices in terms of instructional decision-making processes. Particularly, the study demonstrated that both the implicit and explicit theories are useful tools for teacher preparation and in-service professional development of teachers. Teachers' explicit theory allows them to develop deeper understanding of their children's socio-cultural context, interests, potential and individuality which in turn, serve as basis for making well-informed instructional decisions prior to the commencement of a lesson. This understanding is significant in that more reflective practice can proceed thereafter, to enhance and promote children's development. Importantly, the study also identified the strength of implicit theories of teaching as an alternative reflective practice that may help to point out the nuances within the teaching and learning process to provide a worthwhile means of obtaining observational evidence to promote effective teaching and learning.

\section{References}

Annobil, C. N.; Mumuni, T. Unpacking activities-based learning in kindergarten classrooms: Insights from teachers' perspectives. Educational Research and
Reviews, $\quad$ v. 13, $\quad$ n. 1, p. 21-31, 2018. https://doi.org/10.5897/ERR2017.3397

Berliner, D.C. Expertise: The wonders of exemplary performance. In: Mangieri, J. N.; Block, C. C. (Eds). Creating powerful thinking in teachers and students. Ft. Worth, TX: Holt, Rinehart and Winston, 1994. p. 141-186.

Bernstein, L. Teaching and in English primary schools. Schools Review, v. 8, n. 3, p. 215-244, 1975.

Boeije, H. Analyses in qualitative research. Los Angeles: Sage Publications, 2010.

Bredekamp, S. Effective practices in early childhood educating: Building a foundation. New Jersey: Pearson Education, 2014.

Cevic, Y. D.; Andre, T. Studying the impact of three different instructional methods of preservice teachers' instructional models of preservice teachers' decision-making. Research Papers in Education, v. 29, n. 1, p. 44-68, 2014. https://doi.org/10.1080/ 02671522.2012 .742923

Copple, L.; Bredekamp, S. Developmentally appropriate practice in early childhood programmes serving children from birth through age 8. Washington, D. C.: National Association for the Education of Young Children, 2009.

Hedge, A. V.; Cassidy, R. Teacher' beliefs and practices regarding developmentally appropriate practices in India. Early Childhood Development and Care, v. 179, n. 7, p. 837-847, 2009. https://doi.org/ 10.1080/03004430701536491

Horn, V. L. M.; Ramey, S. A new measure for assessing the early elementary school, a developmentally appropriate practice template. Early Childhood Research Quarterly, v. 19, n. 4, p. 569-587, 2004. https://doi.org/10.1016/j.ecresq.2004.10.002

Hyson, M. C.; Hirst-Pasek, K. H.; Rescorla, L. The classroom practices inventory: an observation instrument based on NAEYC's guidelines for developmentally appropriate practices for 4-5-year-old children. Early Childhood Research Quarterly, v. 5, n. 4, p. 475-494, 1990. https://doi.org/10.1016/ 0885-2006(90)90015-S

Mathew, N. G. Reflective classroom practice for effective classrooms instruction. International Education Studies, v. 5, n. 2, p. 205-2013, 2012. https://doi.org/10.5539/ ies.v5n3p205 
Maxwell, L. K.; McWilliams, A. K.; Hammeter, M. R.; Ault, J. M.; Shuster, W. J. Predictors developmentally appropriate classroom practices in kindergarten-third grade. Early Childhood Education Quarterly, v. 16, n. 4, p. 431-452, 2001. https://doi.org/10.1016/ S0885-2006(01)00118-1

Michell, J. Teachers' implicit theories concerning questioning. British Educational Research Journal, v. 20, n. 1, p. 69-83, 1994. https://doi.org/10.1080/0141192940200107

Ministry of Education. Education reforms in Ghana. 2007. Available from: <http://planipolis.iiep.unesco.org/sites/plan ipolis/files/ressources/ghana_education_ref orm_2007.pdf>. Accessed on: 23 Feb. 2018.

Pedretti, E. Facilitating action research in Science, Technology and Society (STS) education: an experience in reflective practice. Educational Action Research, v. 4, n. 3, p. 207-327, 1996. https://doi.org/ 10.1080/0965079960040303

Spodek, B. Conceptualising today's kindergarten curriculum. The Elementary
School Journal, v. 89, n. 2, p. 203-211, 1988a. https://doi.org/10.1086/461573

Spodek, B. The implicit theories of early childhood teachers. Early Childhood Development and Care, v. 38, n. 1, p. 13-31, 1988b. https://doi.org/10.1080/030044388 0380102

Stake, R. E. Multiple case study analysis. London: Guildford Press, 2006.

Straus, A. Qualitative analysis for the social scientist. New York: Cambridge University Press, 1987.

Thompson, M. Developing the spirituality of children: Observations of teachers in preschool. International Journal of Research in Education, v. 2, n. 8, p. 1-7, 2010.

Yasmin, D. C.; Andre, T. Studying the impact of three instructional methods on presevice teachers' decision-making. Research Papers in Education, v. 29, n. 1, p. 44-68, 2012. http://doi.org/10.1080/02671522.2012.742 923 